\title{
Tumor Results Date and Time of Assessment
}

National Cancer Institute

\section{Source}

National Cancer Institute. Tumor Results Date and Time of Assessment. NCI Thesaurus.

Code C117407.

The date and time of tumor results data collection. 